\title{
THE MOTIVATIONS AND DYNAMICS OF ZIMBABWE'S 2017 MILITARY COUP
}

\author{
BLESSING-MILES TENDI*
}

\begin{abstract}
In November 2017, Robert Mugabe resigned as Zimbabwe's president, following a military action called Operation Restore Legacy. This article examines the motivations and dynamics of Operation Restore Legacy, which it characterizes as a coup by military generals that had significant commonalities with historical coups in Africa. This characterization debunks current interpretations of the coup as 'a non-coup-coup', 'very Zimbabwean' or 'special'. Regarding dynamics, the article argues the coup was a vote of no confidence in Mugabe's leadership, which succeeded because soldiers from Zimbabwe's 1970s independence war subscribed to the coup's stated ideal to restore liberation struggle principles and actors in the ruling Zimbabwe African National Union Patriotic Front (ZANU PF) party. Liberation war veterans held decisive army and air force command posts when the coup occurred. The article's emphasis of liberation struggle principles as a crucial determinant of the coup's success is a counterpoint to game theoretic approaches to coup dynamics that disregard political beliefs as a consequential factor in the realization of coups. In respect of motivations, the article advances a mixed bag of at times interrelating motives and contends that the coup's catalyst was Mugabe's refusal to meet his generals on 13 November, for vital talks on widening differences between both parties. Sealing off dialogue catalyzed the coup.
\end{abstract}

Africa has recorded the highest number of military coups d'état, globally, since 1956. Between 1956 and 2001 there were 80 successful coups d'état, 108 failed coup attempts and 139 reported coup plots across Sub-Saharan Africa. ${ }^{1}$ From 2001 to 2019 approximately a dozen successful coups occurred, mainly in authoritarian West and Central African countries with a history of coups, indicating decreased coup frequency compared with the 1960s to 1980s period, the heyday of coups in Africa. ${ }^{2}$ In November 2017, Zimbabwe underwent its first ever successful military coup, demonstrating that coup risk persists, even in countries without a coup precedent. The coup saw the 93 years old Robert Mugabe resign as Zimbabwe's president, ending 37 years

\footnotetext{
* Miles Tendi is Associate Professor of African Politics in the University of Oxford.

'Patrick McGowan, 'African military coups d'état, 1956-2001: frequency, trends and distribution', Journal of Modern African Studies 41, 3 (2003), pp. 339-370.

${ }^{2}$ Center for Systemic Peace Dataset: 'Coups d'état, 1946-2017', <http://www.systemicpeace.org/inscrdata.html> (20 January 2019).
} 
of his rule, after military generals staged an unconstitutional action called Operation Restore Legacy on 14 November. Emmerson Mnangagwa, a vice president backed by key military generals, was subsequently sworn in as the presidential successor.

Zimbabwean military generals characterized Operation Restore Legacy as 'bloodless' and anything but a coup. ${ }^{3}$ Additionally, supportive politicians in Mnangagwa's Zimbabwe African National Union Patriotic Front (ZANU PF) party and various media and political analysts propagated representations of the operation as 'a military assisted transition', 'non-coup-coup', and 'a modern' coup. ${ }^{6}$ Some scholars have, to a degree, perpetuated these representations through exceptionalist interpretations in the literature, which overstate the Zimbabwe 2017 coup's differences from coups in other African countries. The article considers these representations as problematic and discredits them, arguing that Operation Restore Legacy was a coup that shared comparable justifications and operational attributes with military coups in Africa since 1956. This argument is of pertinence beyond scholars with a narrow interest in Zimbabwean politics. Despite developing into 'anti-coup norm entrepreneurs', a development scholars such as Issaka Soure maintain has contributed to decreasing coup frequency, the African Union (AU) and Southern African Development Community (SADC) did not officially censure or apply sanctions on coup leaders in Zimbabwe. Scholars of African anti-coup norms and practices will find the article a useful starting point for debates about AU and SADC reactions

\footnotetext{
${ }^{3}$ The Herald, 'VP Chiwenga a favourite for Guinness Book of Records', 14 April 2018, <https://www.herald.co.zw/vp-chiwenga-a-favourite-for-guinness-book-of-records/> (20 January 2019).

${ }^{4}$ Financial Times, 'A year in a word: military-assisted transition', 26 December 2017, <https://www.ft.com/content/11fb6f04-e41b-11e7-8b99-0191e45377ec〉 (20 January 2019); International Crisis Group, 'Zimbabwe's “military-assisted transition” and prospects for recovery', 20 December 2017, <https://www.crisisgroup.org/africa/southern-africa/zimbabwe/b134-zimbabwes-military-assisted-transition-andprospects-recovery> (20 January 2019).

${ }^{5}$ Daily Maverick, 'Zimbabwe: when is a coup not a coup?', 20 November 2017,

<https://www.dailymaverick.co.za/article/2017-11-20-zimbabwe-when-is-a-coup-not-a-coup/> (20 January 2019).

${ }^{6}$ The Guardian, 'Zimbabwe's strange crisis is a very modern kind of coup', 21 November 2017,

<https://www.theguardian.com/world/2017/nov/21/zimbabwes-strange-crisis-is-a-very-modern-kind-of-coup> (20) January 2019).

' Issaka Souare, 'The African Union as a norm entrepreneur on military coups d'état in Africa (1952- 2012): an empirical assessment', Journal of Modern African Studies 52, 1 (2014), pp. 69-94.
} 
to the coup and possible future implications of their responses for the legitimacy and efficacy of their broader anti-coup stances.

Turning to its examination of the coup's causes, the article exploits the extant coup motivations literature and draws on interviews with senior military officers and civilian observers of the coup process, to reveal the principal motivations for the coup and the ultimate coup catalyst. The article identifies four main coup motivations: military generals' disgruntlement with Mugabe's downgrading of 1970s liberation struggle actors and ethos in ZANU PF; Mugabe's weakening authority; the personal political leadership aspirations of some generals; and insecurity in the military's upper ranks caused by conditions of precarious tenure and fear of criminal prosecution. 'These motives provide necessary but not sufficient condition for intervention. To move the military to act, these motives have to be catalyzed, ${ }^{8}$ and the catalyst in this instance, the article contends, was Mugabe's rejection of a meeting with his generals on 13 November 2017, to resolve expanding disagreements between both parties. The disputes concerned the aforesaid coup motives. Mugabe's spurning of dialogue catalyzed the coup.

The article underscores the significance of personal ambitions and idiosyncrasies in motivating coups but in the end, it affirms Samuel Finer's assessment that coup motivations are inexorably 'mixed' and the combination of motives tends to vary between cases. ${ }^{9}$ But to conclude the analysis on that point is to reproduce a longstanding limitation of scholarship on coups d'état: its customary concentration on coup motivations and marginalization of grasping coup dynamics. As Naunihal Singh perceptively reminds us, what results in the miscarriage or triumph of a coup deserves as much consideration as a coup's origins. ${ }^{10}$ Thus, the article makes use of interviews with some military actors in the coup, as well as the accounts of two civilians (a Catholic priest called Fidelis Mukonori and Zimbabwe's presidential spokesperson George Charamba), who

\footnotetext{
${ }^{8}$ Samuel Finer, The man on horseback: the role of the military in politics (Routledge, London, 2002), p. 71.

${ }^{9}$ Ibid., p. 58.

${ }^{10}$ Naunihal Singh, Seizing power: the strategic logic of military coups (Johns Hopkins University Press, Baltimore, 2014).
} 
both mediated between Mugabe and military generals during the coup, so as to throw light on the coup's dynamics. The empirical findings inform the article's argument that the coup constituted a vote of no confidence in Mugabe's presidency and that the enduring resonance of liberation struggle values among independence war veterans in the army and air force explains why they broadly agreed to support the coup, as well as why the coup was not reversed by armed actors in the military. The article's stressing of liberation struggle principles as an essential determinant of the coup's accomplishment is a counterpoint to game theoretic models of coup dynamics that discount political beliefs as an important influence in the success of coups. Former liberation war fighters in the military belonged to the Zimbabwe African National Liberation Army (ZANLA) and Zimbabwe People's Revolutionary Army (ZIPRA), which were the liberation armies of two rival nationalist parties, ZANU PF and the Zimbabwe African People's Union (ZAPU), respectively. Ex-ZANLAs have been the majority over former ZIPRAs in the military since the early 1980s." It is mainly this ex-ZANLA majority that believed Mugabe's relegation of liberation struggle actors in ZANU PF was an abrogation of a historically formed normative construction about who ought to rule Zimbabwe, hence their co-operation in the coup. A brief note on access: I have been a scholar of civil-military relations, intelligence studies and ruling party politics in Zimbabwe since 2010. Years of continually interviewing and nurturing relationships of trust with ZANU PF and security sector elites, some of whom were direct participants in or first-hand witnesses to the coup, enabled me to conduct research interviews for this article.

The discussion ahead develops as follows: first, it engages the relevant coup literature, positioning its arguments in relation to existing works. This is followed by a section substantiating the article's characterization of Operation Restore Legacy as a coup. After this, the article

\footnotetext{
${ }^{"}$ Norma Kriger, Guerrilla veterans in post-war Zimbabwe (Cambridge University Press, Cambridge, 2003).
} 
explicates the coup motivations. The final segment of the article expounds the coup's catalyst and dynamics.

\section{Three dimensions of a coup}

The literatures that concern this article encompass three dimensions of a coup: what a coup looks like operationally and how it is justified by perpetrators; the motivations and catalyst for a coup; and a coup's dynamics. I begin by reviewing the first dimension, the justifications and operational attributes of a coup.

In what was partly a reflection of how Zimbabweans imagine their national politics, in relation to the politics of other African countries, one Zimbabwean writer described the 2017 coup as 'very Zimbabwean', as if to distinguish it from 'violent' and 'less stately' unconstitutional changes of government elsewhere in Africa. ${ }^{12}$ A sense of Zimbabwean exceptionalism also underlay some academic studies on the country's politics many years before. ${ }^{13}$ The roots of this exceptionalism can be located in Zimbabwe's 1980s and 1990s strong state bureaucracies, extensive formal sector and substantial public service provision, which 'seemed to mark it out as different from... the experience of those African countries in West and Central Africa that had often provided the empirical basis for theories of state "failure" and social and political disorder'. ${ }^{14}$ However, the advent of Zimbabwe's unexpected post-2000 economic and political crisis, which was typified by massive formal sector breakdown, failing public service provision, mounting state corruption and the politicization of institutions, made wider African Studies debates about neo-patrimonialism and state failure less irrelevant when studying Zimbabwean politics. ${ }^{15}$ There were more unpredicted changes in 2017, through Zimbabwe's inaugural successful military coup. Broader

\footnotetext{
${ }^{12}$ The Guardian, 'Did we panic? No, this was a very Zimbabwean coup', 16 November 2017, <https://www.theguardian.com/commentisfree/2017/nov/16/zimbabwean-coup-robert-mugabe-harare> (20 January 2019).

${ }^{13}$ Jocelyn Alexander and JoAnn McGregor, 'Introduction: politics, patronage and violence in Zimbabwe', Journal of Southern African Studies 39, 4 (2013), pp. 749-763.

${ }^{14}$ Ibid.

${ }^{15}$ Ibid.
} 
debates about military coups are no longer extraneous to academic studies on Zimbabwean politics but the exceptionalism of old endures. The veteran scholar of Zimbabwe studies David Moore, for instance, interprets the 2017 coup as 'very Zimbabwean' and 'a coup of a special type' owing to the fact that 'relatively few people were killed' and the coup was 'remarkably public' and because of the coup's supposed 'ambiguous and elastic texture'. ${ }^{16}$ As accentuated in this article, military coups tend to have context specific motivations, so one might consider the 2017 coup as ‘very Zimbabwean’ strictly in that sense. Nevertheless, drawing on expansive studies about the operational features of coups and how coup doers justify coups in Africa, ${ }^{17}$ this article argues against exceptionalist representations of the 2017 coup as 'very Zimbabwean'. It contends that Operation Restore Legacy was a coup that bore similar operational features and justifications with historical coups in Africa. Military generals, and some ZANU PF politicians and media, also exaggerated the operation's disparities with standard coups because of self-interest, subjectivity and lack of knowledge. Scholars to some extent perpetuate these problematic representations when they employ exceptionalist interpretations of the coup.

With regards to the coup motivations literature, Samuel Decalo emphasizes the import of coup leaders' idiosyncrasies and personal motivations in their decision to launch military coups. ${ }^{18}$ Like Decalo, the article gives weight to the influence of personal ambition and idiosyncrasies, by focusing on the individual motives of Zimbabwe Defence Forces (ZDF) Commander, General Constantino Nyikadzino Chiwenga, the 2017 coup's leader. But although Chiwenga's personal ambition mattered, it overlapped with generalized motivations such as grievance over Mugabe's rising disregard of liberation struggle ethos and actors. Personal motivation alone does not

\footnotetext{
${ }^{16}$ David Moore, 'A very Zimbabwean coup: November 13-24, 2017', Transformation: Critical Perspectives on Southern Africa 97 (2018), pp. 1-29.

${ }^{17}$ The studies are: Staffan Wiking, Military coups in sub-saharan Africa: how to justify illegal assumptions of power (Scandinavian Institute of African Studies, Uppsala, 1983); Ruth First, The barrel of a gun: political power in Africa and the coup d'état (Penguin Books, London, 1972); Jimmy Kandeh, Coups from below: armed subalterns and state power in west Africa (Palgrave Macmillan, New York, 2004); McGowan, 'African military coups d'état'; Finer, The man on horseback.

${ }^{18}$ Samuel Decalo, Coups and army rule in Africa (Yale University Press, New Haven, 1990).
} 
explain why the majority of top officers rallied around Chiwenga to stage the coup. Ultimately, therefore, the article confirms Finer's postulation that coup motivations are often mixed and the composite factors are generally case specific. ${ }^{19}$ The article also finds instructive Finer's observation that 'for motives to be translated into action, something more is required' - a catalyst. ${ }^{20}$ For example, in Uganda despite years of deep political and economic predicaments that the armed forces were not immune from and threats to the army's corporate interests, Idi Amin was irrevocably moved to oust president Milton Obote in a military coup in 1971 because of his impending dismissal from the army and the opening of an investigation into his involvement in murder. ${ }^{21}$ In the Zimbabwean context, Mugabe's snubbing of dialogue with military generals on the morning of 13 November 2017 was the last straw that transmuted motives into action. Some prevailing analyses present Mugabe's sacking of Mnangagwa as vice president on 6 November as the coup catalyst. ${ }^{22}$ For others, Chiwenga's public criticism of Mugabe, on the afternoon of 13 November, meant 'he faced being replaced, arrested and charged with treason. In other words, Chiwenga had little to lose and everything to gain' from staging a coup. ${ }^{23}$ Exploiting the accounts of first-hand observers of the coup process and coup participants themselves, the article remedies these misunderstandings, revealing that the coup catalyst was Mugabe's refusal to meet his generals on 13 November to resolve growing disagreements. The coup did not necessarily take its cue from Mnangagwa's firing and it was already in motion when Chiwenga publicly criticized Mugabe.

\footnotetext{
${ }^{19}$ Finer, The man on horseback.

${ }^{20}$ Ibid., p. 53.

${ }^{21}$ Amii Omara-Otunnu, Politics and the military in Uganda, 1890-1985 (Palgrave Macmillan, London, 2014).

${ }^{22}$ Examples are: Sue Onslow and Martin Plaut, Robert Mugabe (Ohio University Press, Athens, 2018); Brian

Raftopoulos, 'Caught between the croc and gucci city', 23 November 2017,

<http://solidaritypeacetrust.org/1776/zimbabwe-caught-between-the-croc-and-gucci-city/> (20 January 2019); Ray Ndlovu, In the jaws of the crocodile: Emmerson Mnangagwa's rise to power in Zimbabwe (Penguin Books, Cape Town, 2018); Geoffrey Nyarota, The graceless fall of Robert Mugabe (Penguin Books, Cape Town, 2018).

${ }^{23}$ Nic Cheeseman, 'Five tough lessons learnt this year about democracy in Africa', Daily Nation, 10 December 2017

< https://www.nation.co.ke/oped/opinion/-Five-tough-lessons-learnt-this-year-about-democracy-in-Africa-/4408084221482-1uitefz/index.html> (20 January 2019).
} 
As regards the coup dynamics literature, some game theoretic studies comprehend coup processes as coordination. ${ }^{24}$ Singh's work is by far the most sophisticated game theoretic approach to coup dynamics and it includes an African case study (Ghana).$^{25}$ Consequently, the article's discussion of Zimbabwe's 2017 coup dynamics is exclusively concerned with Singh's study. Singh borrows from game theoretic models to conceptualize the strategic logic of coups in terms of coordination. That is to say, in place of political beliefs, self-regard influences coup participants to side with the group they think (correctly or incorrectly) is most likely to be supported by others in the military and prevail in the coup situation. To shape the choice making of the majority of soldiers, coup leaders use information, which is made public through radio and television broadcasts and face-to-face engagements between serving officers, to construct belief in the military that the incumbent leader will definitely lose power through the coup. ${ }^{26}$ This confidence deception brings the majority of decisive actors in the military on the coup leaders' side - since they do not want to wind up on the losing side - resulting in the coup's success. Singh holds that 'whether a coup succeeds or fails rests almost entirely upon what happens within the military'. ${ }^{27}$ Singh first identifies two age-old approaches for understanding why coups triumph or fail. The first approach, found in the work of scholars such as Eric Nordlinger, understands coups as a vote of no confidence that takes place in the military. According to Nordlinger, the success of a coup is decided by an indication in the military of majority support for the incumbent or her/his political adversary. ${ }^{28}$ If the majority of the military no longer continues to support the incumbent, the coup succeeds and the adversary takes power. Singh gleans the second approach from Edward Luttwak's practical handbook on how to plan and conduct an effective coup. Luttwak

\footnotetext{
${ }^{24}$ See: Singh, Seizing power; Barbara Geddes, 'What do we know about democratisation after twenty years', Annual Review of Political Science 2 (1999), p. 115-44; Brett Casper and Scott Tyson, 'Popular protest and elite coordination in a coup d'état', Journal of Politics 76, 2, (2014), pp. 548-64; George-Marios Angeletos, Christian Hellwig and Alessandro Pavan, 'Dynamic global games of regime change: learning, multiplicity, and timing of attacks', Econometrica 75, 3 (2007), pp. 711-56.

${ }^{25}$ Singh, Seizing power.

${ }^{26}$ Ibid.

${ }^{27}$ Ibid., p. 5.

${ }^{28}$ Eric Nordlinger, Soldiers in politics: military coups and governments (Prentice-Hall, Englewood Cliffs, 1977).
} 
partly emphasized the value of coup doers having greater military might than rivals and their implementation of suitable tactics, as key determinants of a coup's success or failure. Luttwak added that a coup's success also hinges on the ability of coup perpetrators to remain 'cloaked in anonymity', conduct their operation with 'maximum speed' and the 'complete neutralization of opponents prior and following the coup ${ }^{29}$ Similarly, Gregor Ferguson and David Hebditch and Ken Connor underline the vitalness of meticulous operational planning for a coup to succeed. ${ }^{30}$ Singh rejects these erstwhile approaches for understanding coup success, arguing that coups do not resemble actual warfare and so the emphasis on military strength, operational precision, tactics and preparedness to use strong violence to defeat resistance is misplaced. ${ }^{31} \mathrm{With}$ respect to coups as votes of no confidence, Singh employs interviews with participants in seven coup attempts that occurred in Ghana between 1967 and 1981, to argue that the political values of soldiers do not shape their choice to support or oppose the incumbent in coup situations.

Singh maintains that generals have the capacity to arrange pivotal pre-coup meetings, at which they 'ensure that the mid-level officers who actually command fighting units believe that the success of the coup is inevitable'. ${ }^{32}$ Certainly, a day before the coup Chiwenga called a security meeting attended by the Army Commander Philip Sibanda, Army Chief of Staff Douglas Nyikayaramba, acting Air Marshal Elson Moyo and dozens of senior and middle level officers that command decisive army and air force formations. However, drawing on accounts by attendees of Chiwenga's security meeting on 13 November, this article argues that the engagement's proceedings and resultant successful coup resembled a vote of no confidence against Mugabe, hence the article sustains the continuing utility of erstwhile approaches, by the likes of Nordlinger, to understanding coup dynamics. The article contradicts Singh's conclusions

\footnotetext{
${ }^{29}$ Edward Luttwak, Coup d'état - a practical handbook (Harvard University Press, Cambridge, 2016), p. 54.

${ }^{30}$ Gregor Ferguson, Coup d'état: a practical manual (Arms and Armour, Poole, 1987); David Hebditch and Ken Connor, How to stage a military coup: from planning to execution (Skyhorse Publishing, New York, 2017).

${ }^{31}$ Singh, Seizing power.

Ibid., p. 10 .
} 
by emphasizing the significance of political convictions in determining a coup's accomplishment or collapse. Singh discounts political beliefs in his conceptualization of coup dynamics as coordination but this article maintains that Zimbabwe's 2017 coup succeeded because it was cast in a defined context suffused with powerful liberation struggle histories and values, which generated support for the coup amongst independence war veterans in control of pivotal army and air force formations. Furthermore, liberation war veterans not in the military organized, on 18 November 2017, a massive inclusive citizens' rally and march in Harare, the capital city, in support of the coup. The march was effectively a second vote of no confidence in Mugabe's leadership by urban citizens this time, and with liberation war veterans as the prime movers once again. The march and generals' action combined to place pressure on Mugabe to resign - a finding that deviates from Singh's contention that a coup's success depends upon intra-military dynamics. Scholars such as Nic Cheeseman have noted that 'the ousting of Mugabe... serves as an important reminder that despite 30 years of multiparty elections in Africa, messing with the military can still be fatal, ${ }^{33}$ A more apposite observation is that the ejection of Mugabe serves as an important reminder that despite approximately 60 years of independence in Sub Saharan Africa, messing with liberation struggle history and values can be fatal because they matter in the politics of some African militaries.

\section{If it looks like a coup... then it is a coup ${ }^{3 t}$}

The path to Mugabe's resignation began on the night of 14 November when Chiwenga authorized a few hundred soldiers, selected from formations such as the SAS, Paratroopers, Presidential Guard and the Mechanized Brigade, amongst others, to launch Operation Restore

\footnotetext{
${ }^{33}$ Cheeseman, 'Five tough lessons'.

${ }^{34}$ I borrow the phrase from Ugandan writer Charles Onyango-Obbo in Washington Post, 'When a coup is not a coup', 15 November 2017, <https://www.washingtonpost.com/news/worldviews/wp/2017/11/15/zimbabwe-when-acoup-is-not-a-coup/?utm_term=.4776dde2fad9> (20 January 2019).
} 
Legacy. ${ }^{3.5}$ The soldiers placed Mugabe under house arrest, took over the government-controlled Zimbabwe Broadcasting Corporation (ZBC) station and they secured other strategic and symbolic sites in and around Harare. Armed soldiers also rapidly neutralized two focal branches of the security sector, the Zimbabwe Republic Police (ZRP) and Central Intelligence Organization (CIO), because military generals considered them potential threats to Operation Restore Legacy's success. Soldiers seized control of the ZRP's Chikurubi armoury and systematically rounded up CIO operatives in order to disarm them. ${ }^{36}$ Furthermore, groups of soldiers conducted violent raids on the family homes of Saviour Kasukuwere, Jonathan Moyo and Ignatius Chombo, ministers in Mugabe's government that some generals disapproved of vehemently. ${ }^{37}$ In the early morning hours of 15 November a serving army Major General called Sibusiso Moyo, accompanied by a senior Air Force officer, then appeared in a live ZBC television broadcast, in which Moyo announced:

His Excellency the President of the Republic of Zimbabwe, Head of State and Government, and Commander in Chief of the Zimbabwe Defence Forces, Comrade R.G Mugabe and his family are safe and sound and their security is guaranteed. We are only targeting criminals around him, who are committing crimes that are causing social and economic suffering in the country, in order to bring them to justice. As soon as we have accomplished our mission we expect that the situation will return to normalcy.... To the judiciary, the measures underway are intended to ensure that as an independent arm of the state, you are able to exercise your independent authority without fear of being obstructed as has been the case with this group of individuals. To members of parliament, your legislative role is of paramount importance for peace and stability in this country. It is our desire that a dispensation is created that allows you to serve your respective constituencies according to democratic tenets. To the world beyond our borders, we wish to make it abundantly clear that this is not a military takeover of government. What the ZDF is doing is to pacify a degenerating social, political and economic situation in our country, which if not addressed may result in a violent conflict. ${ }^{38}$

In 2000, the Organization of African Unity (OAU) passed the Lomé Declaration against unconstitutional changes of government in Africa. The AU succeeded the OAU as Africa's continental body in 2002 and since that time the Lomé Declaration has helped inform its

\footnotetext{
${ }^{35}$ Interview, Senior Military Officer 3, Harare, 13 March 2018; Interview, Senior Military Officer 4, Harare, 16

December 2017.

${ }^{36}$ Interview, CIO Director, Harare, 8 January 2018.

${ }^{37}$ Interview, Saviour Kasukuwere, Johannesburg, 23 July 2018.

${ }^{38}$ Author's personal recording of Major General Sibusiso Moyo’s ZBC live broadcast, 15 November 2017.
} 
normative anti-coup stance. ${ }^{39}$ Coup perpetrators risk encountering AU responses such as public denunciation, suspension from the union and the imposition of sanctions. Likewise, SADC tends to be intolerant of unconstitutional changes of government brought about by military coups d'état in Southern Africa. For these reasons, Major General Moyo's 15 November speech noticeably attempted to frame Operation Restore Legacy as not a coup. He addressed Mugabe as His Excellency the President of the Republic of Zimbabwe, Head of State and Government, Commander in Chief of the Zimbabwe Defence Forces and Comrade, which was performative language designed to ward off charges the military had ceased to be subservient to civilian authority. Major General Moyo claimed Mugabe was 'safe and sound' because he was not Operation Restore Legacy's target. He also conveyed the military's 'respect' for the judiciary and parliament's sanctity and underlined that the military was only assuaging 'a degenerating social, political and economic situation'.

Even though Major General Moyo tried to construct Operation Restore Legacy as not a coup, his justifications for the operation closely resembled validations issued by coup doers in Africa historically. Evidence for this can be found in Staffan Wiking's comparative investigation of the ways in which army officers in Sub-Saharan Africa, from 1958 through to the 1980s, justified political interventions when they made their 'initial declaration (ID) ${ }^{40} \cdot \mathrm{Wiking}$ 's study establishes that 'one can recognize the same types of justifications in the various IDs and one can reduce them to a limited number of recurrent issues'. ${ }^{41}$ Recurrent coup justifications identified by Wiking, which Major General Moyo's ID reiterated, are politicians' misrule, public sector corruption, the nation's socio-economic misery, democratic deficit in the body politic and the short-term nature of the army's selfless intervention to rectify injustices caused by civilian leaders. The lingua franca of restoration is also a recurrent theme in coup IDs. The perpetrators of

\footnotetext{
${ }^{39}$ Souare, 'The African Union'.

${ }^{40}$ Wiking, Military coups, p. 13.

${ }^{41}$ Ibid., p. 72.
} 
Niger's 2010 coup dubbed themselves the 'Supreme Council for the Restoration of Democracy', the leaders of Gabon's January 2019 unsuccessful coup called themselves the 'National Restoration Council', while Zimbabwe's Operation Restore Legacy referred to the restoration of the authority of liberation struggle actors and values in ZANU PF and the presidency.

In addition to the contents of Major General Moyo's ID, Operation Restore Legacy bore other hallmarks of coups d'état, such as a uniformed serving army officer announcing on national radio and television the military's political intercession and soldiers' occupation of the country's strategic and symbolic locations and routes. Moreover, there is a long history of coups, such as those in Benin (1963), Uganda (1971), Ghana (1979), Liberia (1980), Mali (1991), Sierra Leone (1992) and Niger (2010), which received tacit or overt public backing from citizenry. ${ }^{42}$ Like these past coups, Operation Restore Legacy received public support, in this case through urbanites' marches in solidarity with the coup on 18 November. In light of the abovementioned evidence, some scholars' exceptionalist interpretations of the coup as 'very Zimbabwean' or 'special' are difficult to sustain.

In coup instances 'the degree of violence involved can range from none, so called "bloodless coups”, to pronounced'. ${ }^{43}$ Examples of bloodless coups are Sierra Leone (1968), Nigeria (1985) and Gambia (1994), whilst Liberia (1980), Burkina Faso (1987) and Sierra Leone (1997) were bloody affairs." That said, military coups are relatively peaceful occurrences, given that it is not the norm for them to degenerate into out-and-out civil conflict. ${ }^{45}$ Yet Zimbabwean generals presented Operation Restore Legacy as bloodless, violence free and non-destructive of property, suggesting these virtues made it distinct from a coup. ${ }^{46}$ Generals' stance Operation Restore Legacy was bloodless was a distortion of facts, since one CIO operative died during the

\footnotetext{
${ }^{42}$ Kandeh, Coups from below.

${ }^{43}$ McGowan, 'African military coups'.

${ }^{44}$ Issaka Souare, Civil wars and coups d'état in west Africa (University Press of America, New York, 2006).

${ }^{45}$ Singh, Seizing power.

${ }^{46}$ The Herald, 'VP Chiwenga a favourite'; The Herald, 'We are heartened by your support', 21 November 2017, <https://www.herald.co.zw/we-are-heartened-by-your-support/> (20 January 2019).
} 
operation, ${ }^{47}$ although military officers I interviewed claimed two CIO operatives were killed, along with an unspecified number of private bodyguards belonging to Chombo. ${ }^{18}$ Certain CIO operatives were tortured by soldiers during Operation Restore Legacy. ${ }^{49}$ Furthermore, generals' assertion their operation did not result in property losses was challenged by Kasukuwere, who narrated how soldiers fired dozens of bullets at his Harare residence, destroying belongings, on the night of 14 November. ${ }^{50}$ Similarly, Moyo and Chombo rendered accounts of destructive raids on their Harare properties. ${ }^{51}$ Be that as it may, sections of international media and some political analysts marveled at the supposed 'gentle', 'peaceful', 'soft', 'polite' and 'modern' nature of Operation Restore Legacy and at Zimbabwean urbanites' generally unfussed reaction, in public at least, to armed soldiers and armoured cars deployed on the capital's streets. ${ }^{52}$ This misreading of Operation Restore Legacy was because some media and political analysts were uninformed about the nature of coups and actual events in Zimbabwe at the time. Mugabe was also a much demonized and unpopular figure in Western media circles especially, ${ }^{53}$ which helps explain why certain media minimized their criticisms of Operation Restore Legacy. Subjective and uninformed media representations, wittingly or unwittingly, played into generals' self-serving portrayal of their operation as not a coup.

\footnotetext{
${ }^{47}$ VOA Zimbabwe, 'Zimbabweans hold memorial service for CIO boss killed in November military intervention', 23 January 2018, <https://www.voazimbabwe.com/a/zimbabwe-relatives-of-slain-cio-operative/4228254.html> (20) January 2019).

${ }^{48}$ Interview, Senior Military Officer 3, Harare, 13 March 2018; Interview, Senior Military Officer 4, Harare, 16 December 2017.

${ }^{19}$ The Citizen, 'How Mugabe's inner circle was severely beaten by soldiers during army takeover', 20 November 2017, <https://citizen.co.za/news/news-africa/1733921/how-mugabes-inner-circle-was-severely-beaten-by-soldiersduring-army-takeover/> (20 January 2019).

${ }^{50}$ Interview, Saviour Kasukuwere, Johannesburg, 23 July 2018.

${ }^{51}$ Zimbabwe Independent, 'Chombo demands post-coup justice', 13 July 2018, <https://www.theindependent.co.zw/2018/07/13/chombo-demands-post-coup-justice/> (20 January 2019).

${ }^{52}$ Illustrations are: The Guardian, 'Zimbabwe's strange crisis'; CNN, 'Zimbabwe's military takeover was the world's strangest coup', 21 November 2017, <https:/edition.cnn.com/2017/11/20/africa/zimbabwe-military-takeoverstrangest-coup/index.html> (20 January 2019); Washington Post, 'Please do not call what is happening in Zimbabwe a “coup”', 16 November 2017, <https:/www.washingtonpost.com/news/democracypost/wp/2017/11/16/just-dont-call-whats-happening-in-zimbabwe-a-coup/?utm_term=.90050817e4d3> (20 January 2019).

${ }^{53}$ Blessing-Miles Tendi, 'The origins and functions of demonisation discourses in Britain-Zimbabwe relations (2000- )', Journal of Southern African Studies 40, 6 (2014), pp. 1251-1269; Wendy Willems, 'Remnants of empire? British media reporting on Zimbabwe', Westminster Papers in Communication and Culture 2, 11 (2005), pp. 91-108.
} 
Ruth First, in her classic text on military takeovers, writes that 'coups d'état involve the army as principal protagonist and conspirator, even if it withdraws to the barracks once the action is over' ${ }^{54}$ Likewise, Finer's The Man on Horseback, another mainstay in the civil-military relations literature, identifies the army as the chief coup executor. ${ }^{55}$ The Zimbabwean military's conduct, in Operation Restore Legacy, was definitely that of 'principal protagonist and conspirator', a point that will be further substantiated in the next section. What is more, following First's characterization, the military's withdrawal to the barracks after Mugabe resigned and a new civilian authority had been sworn in, does not disqualify Operation Restore Legacy as a coup. An alternative edifying coup definition is offered by Patrick McGowan, who draws from Luttwak's contention that 'a coup consists of the infiltration of a small but critical segment of the state apparatus which is then used to displace the government from its control of the remainder ${ }^{, 56}$ McGowan's definition of coups d'état is more expansive: coups are 'events in which existing regimes are suddenly and illegally displaced by the action of a relatively small group, in which members of the military, police or security forces of the state play a key role, either on their own or in conjunction with civilian elites such as civil servants, politicians and monarchs. ${ }^{57}$

My initial sketch of Operation Restore Legacy as involving a limited group of military actors playing a central role in Mugabe's displacement corresponds with McGowan's coup definition. Crucially, McGowan's definition highlights illegality. Section 213 (1) of Zimbabwe's Constitution lays down that 'only the President, as Commander in Chief of the Defence Forces, has power (a) to authorize the deployment of the Defence Forces; or (b) has power to determine the operational use of the Defence Forces ${ }^{58}$ Mugabe did not authorize Operation Restore Legacy, making it an unlawful action in the mould of a coup by generals. Although the generals denied

\footnotetext{
${ }^{54}$ First, The barrel of a gun, p. 19.

${ }^{55}$ Finer, The man on horseback.

${ }^{56}$ Luttwak, Coup d'état, p. 12.

${ }^{57}$ McGowan, 'African military coups'.

${ }^{58}$ 'Constitution of Zimbabwe' (Government Printers, Harare, 2013), p. 91.
} 
they were in charge of Zimbabwe during Operation Restore Legacy, their refutation is untenable given that Mugabe was mostly under house detention and effectively divested of his constitutional powers, and Military Intelligence (MI) was spying on all communications to and from the Mugabe's household. ${ }^{59}$ As First aptly put it, when effecting a coup 'arrest the person of the president, and you arrest the state' ${ }^{60}$ On 17 November, Mugabe made a surprise appearance at a university graduation ceremony in his capacity as Head of State and Chancellor of all state-run universities. Mugabe's attendance of the ceremony was mere performance sanctioned by generals as a means of upholding a façade that civilian authority subsisted in Zimbabwe. ${ }^{61}$ In addition, the fact that ZRP and CIO were out of action during Operation Restore Legacy, left policing and border control responsibilities to the military, whilst the protection of national security now fell under MI, all of which gave the military de facto rulership. ${ }^{62}$ Lastly, subsequent to Mnangagwa's inauguration as president, Chiwenga became a Vice President and Defence Minister concurrently, Major General Moyo was appointed Foreign Affairs Minister and the Zimbabwe Air Force Marshal Perrance Shiri the Agriculture Minister, in a civilian-military coalition government.

Operation Restore Legacy was more or less a coup. The coup was not 'bloodless' or 'polite'. Neither was it 'modern', 'very Zimbabwean' or 'special' because its ID and operational procedures resembled historical coups. Philip Roessler points out:

the African Union faced a conundrum: condemn the coup and the ZDF's de facto seizure of power but be seen (once again) to be shielding Mugabe from his political reckoning.... In narrowly focusing on the removal of the sitting head of state as the defining feature of a coup rather than the unconstitutional use of force to coerce elected leaders to relinquish power, it sets a dangerous precedent that threatens to undermine the strong gains the region has made to move beyond politics by the gun. ${ }^{63}$

\footnotetext{
${ }^{59}$ Interview, Senior Military Officer 3, Harare, 13 March 2018; Interview, Senior Military Officer 4, Harare, 16 December 2017.

${ }^{60}$ First, The barrel of a gun, p. 4.

${ }^{61}$ Interview, Father Fidelis Mukonori, Harare, 4 January 2018; Interview, George Charamba, Harare, 24 December 2017.

${ }^{62}$ Interview, Senior Military Officer 3, Harare, 13 March 2018; Interview, Senior Military Officer 4, Harare, 16 December 2017.

${ }^{63}$ Philip Roessler, 'How the African Union got it wrong on Zimbabwe', 5 December 2017, <https://www.aljazeera.com/indepth/opinion/african-union-wrong-zimbabwe-171204125847859.html> (20 January 2019).
} 
The precise reasons why the coup passed without AU and SADC condemnation and the consequences of this, going forward, for the legitimacy and efficacy of their anti-coup stances are subjects beyond the scope of this article. Suffice it to say Roessler might well be correct in his consideration. I now turn to a discussion of the coup's predominant motivations.

\section{Losing confidence in 'old man Machiavelli'}

This section expounds the four prime coup motivations. The first motivation was what top to middle rank military officers, with liberation war experience, saw as Mugabe's disagreeable downgrading of liberation struggle values and actors in ZANU PF between 2015 and 2017. The second coup motivation was that in this two-year period, senior military officers progressively felt insecure under Mugabe's command. A third motivation was the erosion of Mugabe's once commanding authority over generals. The fourth coup motivation was that politically ambitious generals, Chiwenga primarily, now regarded Mugabe as an obstacle to the achievement of their personal aims to govern Zimbabwe. I begin by focusing on the first coup motivation, which centred on Mugabe's marginalization of liberation struggle values and actors.

In December 2014, Mugabe purged then vice president Joice Mujuru and some of her supporters in ZANU PF because he considered them a threat to his hold on power. ${ }^{64}$ Mugabe subsequently appointed Mnangagwa and Phelekezela Mphoko as the two new vice presidents but the changes were also noteworthy because they signalled the elevation in ZANU PF structures of some party leaders with no substantial connection to the independence war. Some cases in point were Mugabe's appointment of Grace Mugabe as leader of the ZANU PF Women's League, Kasukuwere's promotion to the instrumental National Political Commissar post and latterly Kudzanai Chipanga's selection as head of the party's Youth League. These and other

\footnotetext{
${ }^{64}$ Blessing-Miles Tendi, 'State intelligence and Zimbabwe's presidential succession politics', African Affairs 115 , 459 (2016), pp. 203-224.
} 
politicians devoid of liberation struggle experience were labelled the Generation 40 (G40) faction by local political journalists. Politicians labelled G40 did not all self-identify as G40 members, they did not necessarily have a collective policy platform and not all of them were without liberation struggle experience. ${ }^{65}$ Nevertheless, most of these politicians were generally united by mutual opposition, which had a range of sources, towards Mnangagwa's faction in ZANU PF. ${ }^{66}$ Certain G40 politicians had Mugabe's covert backing, ${ }^{67}$ which aided G40's emergence as a challenger to Mnangagwa's faction in the contest to succeed Mugabe, with liberation history and values being a key site of contestation.

In May 2015, Moyo, a cabinet minister connected with G40, was interviewed on the British Broadcasting Corporation's (BBC) Hardtalk programme. Moyo criticized the interviewer's suggestion that Mnangagwa was 'the heir apparent' and he branded Mnangagwa as simply Mugabe's assistant. ${ }^{68}$ Moyo regularly attacked Mnangagwa via his Twitter handle, typecasting him as a 'successionist' who was out to depose Mugabe. ${ }^{69}$ Moyo also slated Mnangagwa for 'corrupting' the ZANU PF government's Command Agriculture programme:

[a] strategic maize import substitution programme that we all supported when it was initiated in the Politburo by... Grace Mugabe, has been hijacked and corrupted by successionists who are implementing it through a task force, headed by... Mnangagwa, whose modus operandi effectively side-lines the Ministry of Agriculture in favour of an unaccountable military structure run by soldiers. [That] violates government procedures and the law, rips off farmers and uses the programme as a parallel structure for positioning and projecting...

Mnangagwa not only as a maize mesh, but as the anointed successor. ${ }^{70}$

Grace Mugabe backed Moyo in his attacks on the Mnangagwa group. She publicly censured veterans of the liberation war, some of whom were associated with Mnangagwa's leadership bid, for attempting to disqualify politicians without struggle credentials from leadership roles. After a

\footnotetext{
${ }^{65}$ Interview, Saviour Kasukuwere, Johannesburg, 23 July 2018.

${ }^{66}$ Ibid.

${ }^{67}$ Interview, Saviour Kasukuwere, Harare, 13 December 2015.

${ }^{68}$ BBC Hardtalk, 18 May 2015, <https://www.bbc.co.uk/programmes/b05vrbjj> (20 January 2019).

${ }^{69}$ The Standard, 'Mugabe succession: Jonathan Moyo bares it all', 7 February 2016, <https:/www.thestandard.co.zw/2016/02/07/mugabe-succession-jonathan-moyo-bares-it-all/> (20 January 2019).

${ }^{70}$ The Standard, 'The big interview: Prof Moyo savages General Chiwenga', 2 July 2017, <https://www.thestandard.co.zw/2017/07/02/prof-moyo-savages-general-chiwenga-takes-aim-ed/>, (20) January 2019).
} 
murky bombing attempt at the Mugabes' Alpha Omega dairy processing factory in January 2016, Grace Mugabe publicly claimed military generals arranged the sabotage and she accused generals of a 'demonic' plot to eliminate her son Bellarmine. ${ }^{71}$

Mnangagwa largely desisted from disparaging G40 in public but his ally in the military Chiwenga was unrestrained. Chiwenga issued a riposte, which referenced liberation struggle codes of conduct, to Moyo's public reproaches of Command Agriculture:

it was unthinkable during the liberation struggle for senior officials to leak private discussions held by the leadership for their own selfish ends. We have fought a bitter armed struggle [against colonialism] and we have never seen it that whatever was discussed at the High Command was leaked to the cadres. What was discussed at the Central Committee of the party was respected and they would only tell the cadres what they need to know. ${ }^{72}$

Chiwenga evidently intimated that Moyo, and by extension G40, lacked party discipline and selflessness because they were absent in the liberation struggle, in which appropriate political orientation and self-sacrifice values were inculcated. Shiri waded into the public acrimony between some G40 politicians and former liberation struggle actors. Shiri called Moyo a liberation war deserter and he alleged that Moyo was a sell-out because he had links to Rhodesian colonial organizations in the $1970 \mathrm{~s} .{ }^{73}$ What was remarkable about Shiri's intervention is that ordinarily he and Chiwenga were not of the same mind. ${ }^{44}$ Chiwenga and Shiri had a frictional relationship, which partly centred on an authority struggle between them. In 1992, Vitalis Zvinavashe was appointed Army Commander and Shiri the Air Marshal. Two years later, the post of ZDF Commander, with overall command of the Army and Air Force, was established and taken up by Zvinavashe and Chiwenga replaced him as Army Commander. Shiri remained in his Air Marshal post and so he had served as a Service Chief for two years before Chiwenga

\footnotetext{
${ }^{71}$ The Herald, 'First lady dares lacoste group as she threatens to name, shame factionalists and alleges army involvement in bombing', 13 February 2016,

<https://www.herald.co.zw/first-lady-dares-lacoste-group •-threatens-to-name-shame-factionalists- •-alleges-armyinvolvement-in-bombing/> (20 January 2019).

${ }^{72}$ Chronicle, 'Chiwenga warns Prof Moyo', 26 June 2017, <http://www.chronicle.co.zw/chiwenga-warns-profmoyo/> (20 January 2019).

${ }^{73}$ The Sunday Mail, 'Air marshal exposes Professor Moyo lies', 9 July 2017, <http://www.sundaymail.co.zw/airmarshal-exposes-professor-moyo-lies/> (20 January 2019).

${ }^{74}$ Interview, Senior Military Officer 1, Harare, 9 December 2017.
} 
became one. In part because of this fact of seniority, Shiri was the first choice for the ZDF Commander post when it fell vacant upon Zvinavashe's retirement in 2003 but he declined the appointment for personal reasons. ${ }^{75}$ Consequently, Chiwenga was promoted as ZDF Commander and Shiri remained in his post as Air Marshal but he regarded himself as senior to Chiwenga, he was not consistently in agreement with Chiwenga's ZDF management practices and both men had dissimilar temperaments. ${ }^{76}$ In 2008 , Shiri was shot by unknown armed assailants while driving to his commercial farm. ${ }^{77}$ Dumiso Dabengwa, a former Home Affairs Minister with responsibility for the ZRP, noted that:

The attempt on Shiri's life was never solved. People who had no idea about what happened to Shiri were picked up. The police homicide unit had an eight out of ten rate of catching those who attempt or commit homicide. They were good and for an important person like Shiri, they should have been able to catch those people. ${ }^{78}$

A senior figure in the ZRP echoed Dabengwa's views about the suspicious nature of Shiri's shooting:

There is no way Shiri can be shot on his farm road, on a route that he knows well, shot by people with AK- $47 \mathrm{~s}$ and then you say its foreigners who tried to kill him or its thieves who tried to kill him. No! Those were army guys. Ikoko ku defence. Ndivo vaida kumupedza [those in Defence wanted to finish him], and that I am convinced. That is why our investigation did not succeed because anything that is done by people who are internal, those who are in the system, you will never find the truth of the matter. ${ }^{79}$

Despite these divisive intra-military intrigues, Shiri allied with fellow officers from the independence war in publicly constructing some G40 elements as independence war deserters and sell-outs unfit for the ZANU PF leadership, underlining the strength of liberation struggle solidarity bonds.

Some liberation war veterans outside the military were equally censorious of G40. They denounced Kasukuwere for increasingly marginalizing war veterans in ZANU PF structures, in

\footnotetext{
${ }^{75}$ Ibid.

${ }^{76}$ Ibid.

${ }^{77}$ The Telegraph, 'Zimbabwe air force chief survives "assassination attempt”, 16 December 2008, <https://www.telegraph.co.uk/news/worldnews/africaandindianocean/zimbabwe/3793119/Zimbabwe-air-forcechief-survives-assassination-attempt.html> (20 January 2019).

${ }^{78}$ Interview, Dumiso Dabengwa, Bulawayo, 27 August 2011.

${ }^{79}$ Interview, Senior Police Commissioner, Harare, 4 April 2014.
} 
his position as the party's National Political Commissar. ${ }^{80}$ Veterans of the liberation war also demanded that Kasukuwere be dismissed from ZANU PF by Mugabe. ${ }^{81}$ In February 2016, war veterans convened a major gathering in Harare, in order to stage an anti-G40 protest. Mugabe responded by deploying anti-riot police that dispersed the veterans using teargas and water cannons. Karen Nehanda, a war veteran, commented on the police's heavy handedness:

We just need someone to explain to us what is happening. How can someone say down with comrades [veterans of liberation war]? Which country has ever rejected its own war veterans? Even those who went to World War I are still being celebrated, they celebrate their veterans in America, they celebrate their founding fathers but in ZANU PF, we feel that the way we love our president and our party, the way we love our nationalists as fighters, they have to love us back. ${ }^{82}$

In November 2016, senior serving and retired members of the military, some war veterans and Mnangagwa converged in a rural district called Uzumba, for an official opening of a health clinic. ${ }^{83}$

During the ceremony a retired army officer made the following recommendation to Chiwenga:

.... [the retired officer] said to Chiwenga in our presence, "Mugabe is going to kill you very soon. Do a coup. If you do not do a coup your head will be cut off and after that $\mathrm{G} 40$ will come after all comrades and clean us out. They will make us irrelevant. G40 will finish us'. There was concern about G40 by comrades. G40 over played the anti-liberation war card. .... [the retired officer] is not Chiwenga's friend but he felt threatened by G40. What.... [the retired officer] said at that event is what many war veterans were saying. I am also not Chiwenga's supporter but I felt the same way. So you see, unlikely bedfellows were united by Mugabe and G40. ${ }^{8+}$

Tellingly, Chiwenga did not rebuke or endorse the retired army officer's counsel he stage a coup, he only grinned, suggesting resort to a coup may not have been far from his ongoing calculations. ${ }^{85}$ And if a coup was not outside Chiwenga's scheming, calls for a coup from 'unlikely bedfellows' possibly encouraged a belief in Chiwenga that a coup designed to preserve the status of liberation

\footnotetext{
${ }^{80}$ Newsday, 'Kasukuwere, war vets feud over elections', 25 October 2016,

<https://www.newsday.co.zw/2016/10/mdc-t-audacious-police-band-appeal/> (20 January 2019).

${ }^{81}$ The Herald, 'Moyo, Kasukuwere must go: war vets', 9 February 2016, <https://www.herald.co.zw/moyokasukuwere-must-go-war-vets/> (20 January 2019).

${ }^{82}$ African News Agency, 'Mugabe regime turns on war veterans', 18 February 2016,

<https://www.iol.co.za/news/africa/mugabe-regime-turns-on-war-veterans-1986645> (20 January 2019).

${ }^{83}$ The Herald, 'VP Mnangagwa calls for unity', 14 November 2016, <https://www.herald.co.zw/vp-mnangagwacalls-for-unity/> (20 January 2019).

${ }^{84}$ Interview, Liberation War Veteran 1, Harare, 12 March 2018.

${ }^{85}$ Ibid.
} 
struggle actors and values was likely to receive support from struggle veterans in and outside the military.

Mugabe did not heed public and private remonstrations by generals and war veterans that he rein in G40. ${ }^{86}$ For instance, in September 2017, Mugabe selected a five-member Elections Directorate, tasked with superintending ZANU PF's campaign preparations for the 2018 elections. The Elections Directorate comprised Kasukuwere, Grace Mugabe, Chombo, Chipanga and the Finance Minister Patrick Chinamasa ${ }^{87}$ Of these five members, only Chinamasa belonged to Mnangagwa's faction. More importantly, all five members did not participate in the independence struggle. The appointments reinforced a perception that Mugabe had abandoned liberation struggle stalwarts and appeared to be positioning G40 to takeover ZANU PF. With regard to generals, in July 2017 Mugabe reproved them for interfering in ZANU PF politics and warned that doing so was equivalent to 'a coup' because 'politics shall always lead the gun and not the gun politics' ${ }^{88}$ The notion of politics leading the gun was an invocation of a ZANU PF liberation war time principle that it was mandatory for the ZANLA army to remain subservient to politicians and the party. In addition, Mugabe publicly declared that he intended to 'retire' the military leadership in due course, underscoring his deteriorating relations with top officers. ${ }^{89}$

The second coup motivation was some generals' acute sense of insecurity, caused by Mugabe's specified plan to retire some military generals. A military officer further elaborated:

Mugabe did many JVs (joint ventures) with some of the generals and Mnangagwa. JVs started with corruption in the DRC [where the Zimbabwean military staged an intervention in 1998]. There were also JVs of corruption in ZANU PF companies like Tregers. Then there were JVs about eliminations of people. After all these JVs Mugabe was now starting to pull away and they became worried..$^{90}$

\footnotetext{
${ }^{86}$ Interview, George Charamba, Harare, 24 December 2017.

${ }^{87}$ Chronicle, 'President appoints ZANU PF elections directorate', 13 September 2017, <http://www.chronicle.co.zw/president-appoints-zanu-pf-elections-directorate/> (20 January 2019).

${ }^{88}$ News24, 'Mugabe accuses military of plotting a coup, tells them "stop interfering in politics”, 29 July 2017, <https://www.news24.com/Africa/Zimbabwe/mugabe-accuses-military-of-plotting-a-coup-tells-them-stop-interfingin-politics-20170729> (20 January 2019).

${ }^{89}$ The Standard, 'Mugabe: generals face the axe', 30 July 2017,

<https://www.thestandard.co.zw/2017/07/30/mugabe-generals-face-axe/> (20 January 2019).

${ }^{90}$ Interview, Senior Military Officer 1, Harare, 9 December 2017; On Mnangagwa and some military officers' alleged corruption in the Democratic Republic of Congo, see: United Nations, 'Final report of the panel of experts on the illegal exploitation of natural resources and other forms of wealth of the Democratic Republic of the Congo', <http://www.securitycouncilreport.org/un-documents/document/DRC\%20S\%202002\%201146.php>
} 
Compromised generals believed Mugabe intended to use the ZRP to arrest them for corruption. 'Two weeks before the coup the police were ready to deal with the army commanders. We had upped security at our homes and we were carrying AK-47s in the boots of our cars', recalled one top military officer. ${ }^{91}$ Another senior officer averred:

During the Christmas holiday of 2015, [ZRP Commissioner General Augustine] Chihuri spent time with Mugabe in Dubai. They were planning to arrest people. After Chihuri came back, he started pushing an agenda to create space in prisons. Chihuri was very involved in that. I suspected a big witch-hunt was coming. That made me afraid. At about that same time, comrades were teargassed by Chihuri's police. ${ }^{92}$

Top officers suspected the corruption charges they were likely to face included their unethical involvement in alluvial diamond mining projects in the Marange region of Eastern Zimbabwe. ${ }^{93}$ The Command Agriculture programme, in which some high-ranking military officers had directorship roles, was also rife with corruption accusations. ${ }^{94}$ Fear of prosecution for Command Agriculture corruption was heightened by Chombo's replacement of Chinamasa as Finance Minister in October 2017. Chombo had stronger allegiance to Mugabe, resulting in some military officers becoming apprehensive that Chombo had been given a brief by Mugabe to compile evidence of misallocation of treasury funds in the Command Agriculture programme. ${ }^{95}$

Chihuri and the ZRP's perceived status as Mugabe's chosen security sector arm for carrying out arrests of some military officers requires clarification. The police development scholar Alice Hills observes that chief police officers in Africa 'rarely lead coups, though they may be involved in them, and Ghana's 1966 coup remains one of the rare examples in which police are known to

(20 January 2019); On Mnangagwa's alleged looting of ZANU PF companies, see: Martin Dawson and Tim Kelsall, 'Anti-developmental patrimonialism in Zimbabwe', Journal of Contemporary African Studies, 30, 1 (2012).

${ }^{91}$ Interview, Senior Military Officer 4, Harare, 16 December 2017.

${ }^{92}$ Interview, Senior Military Officer 3, Harare, 13 March 2018.

${ }^{93}$ Ibid.; On some top military officers' corrupt activities in Marange, see Richard Saunders and Tinashe Nyamunda (eds), Facets of power: politics, profits and people in the making of Zimbabwe's Blood Diamonds (Wits University Press, Johannesburg, 2016).

${ }^{9}$ Newsday, 'Command agriculture: there is no harm in openness', 3 July 2017,

<https://www.newsday.co.Zw/2017/07/command-agriculture-no-harm-openness/> (20 January 2019).

${ }^{95}$ Interview, Senior Military Officer 1, Harare, 9 December 2017. 
have initiated and organized political action ${ }^{96}$ Police mostly perpetuate, not overturn, the status quo, since ruling 'regimes impose heavier burdens for regime maintenance on them' ${ }^{97}$ The police force is also bereft of resources (tanks and armoured cars), tactical training and institutional capacity to mount coups. Furthermore, the localized character of everyday policing normally makes police officers disengage with wider national security questions and elite politics. ${ }^{98}$ Hills' explanations help us comprehend why the ZRP mostly continued to do Mugabe's bidding, but they tell us nothing about how demands placed on ZRP by Mugabe, interacted with Chihuri's personal preferences in the presidential succession competition. Chihuri was an independence war veteran but he did not side with his struggle comrades in the military against G40. His decision not to oppose G40 was informed by his aversion to Mnangagwa, which began in the 1970s liberation war, and because of his political allegiance to Joice Mujuru, once a frontrunner in the presidential succession race, who he described as his 'niece'. ${ }^{99}$ Chihuri disagreed intensely with Mugabe's purge of Joice Mujuru in 2014, which benefited his adversary Mnangagwa politically. Thus, he refused to side with the Mnangagwa faction against G40, even though Mnangagwa's group had from 2015 onward grown to represent the interests of many liberation struggle actors in ZANU PF. But Chihuri loathed Mnangagwa chiefly because of their spiteful history in the liberation struggle. Chihuri, then a ZANLA military training instructor, was in 1978 incarcerated for purportedly plotting to stage a coup against the ZANU PF leadership. On the word of Chihuri, ZANU PF's security department, which was overseen by Mnangagwa, falsified intelligence to implicate him in the purported coup scheme. ${ }^{100}$ Chihuri was imprisoned from 1978 until the end of the liberation war in December 1979. He was tortured and resided in squalid prison conditions. After release, Chihuri found that Mnangagwa had been romantically involved

\footnotetext{
${ }^{96}$ Alice Hills, 'Henchmen - or why police don’t mount coups', The RUSIJournal, 154, 4 (2009), pp. 14-19.

${ }^{97}$ Ibid.

${ }^{98}$ Ibid.

${ }^{99}$ Interview, Augustine Chihuri, Harare, 15 April 2015.

${ }^{100}$ Ibid.
} 
with his lover while he was in prison and Chihuri endured stigma in ZANU PF for being a 'counter-revolutionary' in the liberation war, a charge he refuted.${ }^{101}$ Chihuri's account validates the enduring significance of liberation war time histories and it showcases how these histories sometimes stimulated contradictory behaviours. Liberation history and struggle values influenced the convergence of many independence war participants in opposition to G40, but in some cases, like that of Chihuri and Mnangagwa, they sustained lasting divisions between ex-liberation struggle partakers.

The discussion now concentrates on the third coup motivation, Mugabe's dwindling charismatic authority and subjection to subordinate masculinity. The loyalty of some generals to Mugabe was changeable and contradictory historically. Nonetheless, Mugabe maintained authority owing to his Commander in Chief rank and his discerning use of patronage to sustain officers' allegiance, ${ }^{102}$ and because of his charismatic authority and militant hegemonic masculinity. From these varied sources of authority, it is the latter two that mainly degenerated between 2015 and $2017 .^{103}$ Mugabe's declining charismatic authority and subjection to a subordinate masculinity constituted his decreasing authority over generals. I first explicate Mugabe's abating charismatic authority. Mugabe was a multifaceted political leader wielding Weberian type charismatic authority in ZANU PF. To paraphrase Max Weber's description of charismatic authority, many ZANU PF followers had 'devotion to the specific sanctity, heroism or exemplary character of' Mugabe, as well as 'the normative patterns or order revealed or ordained by him'. ${ }^{104}$ This was because Mugabe was a founding father of independent Zimbabwe and a founder member of ZANU PF in 1963. Mugabe modelled himself as an unfailing anti-imperialist. Political uses of liberation history flowed through Mugabe, as seen in his post-independence delineation of 'patriotic

\footnotetext{
${ }^{101}$ Ibid.

${ }^{102}$ Blessing-Miles Tendi, 'Ideology, civilian authority and the Zimbabwean military', Journal of Southern African Studies 39, 4 (2013), pp. 829-843.

${ }^{103}$ Interview, Senior Military Officer 3, Harare, 13 March 2018.

${ }^{104}$ Max Weber, Economy and society: an outline of interpretive sociology (Bedminster Press, New York, 1968), p. 215.
} 
history', a narrative concerning resonant ideas about patriotism and sovereignty and compelling black grievances about land and racial injustices..$^{105}$ Major General Happyton Bonyongwe, Mugabe's longest serving CIO Director General (2003-2017), recounted that Mugabe occasionally held court, encased by senior civil servants, his vice presidents and security chiefs: 'he would talk with no notes, non-stop for hours about history, the country and current affairs. His mind was so clear, very detailed, it was captivating, ${ }^{106}$ Mugabe was one of the most highly educated politicians in ZANU PF's top leadership and he spoke perfect Edwardian English with a refined accent, in his vibrant speechifying, all of which reinforced his charismatic authority, owing to the veneration of education in Zimbabwean politics. But Mugabe's status as an iconic leader was also a construction of his followers, as observed by Edgar Tekere and Enos Nkala, Mugabe's contemporaries in ZANU PF from the early 1960s through to the independence years. ${ }^{107}$ One cannot entirely cognize Mugabe's 37 years of rule without positioning in a single frame the dynamism of his charismatic authority and political followers' susceptibilities and subjective constructions of Mugabe the icon. However, Mugabe, a nonagenarian, underwent hastening mental decline in the period that concerns this article. His once magnetic oratory skills also atrophied. Mugabe now spoke with a weary inflection, eyes shut, and his body leaning against the podium during public addresses. Charamba, in his function as the president's press secretary, delivered regular press briefings to Mugabe. 'This year [2017] RG's [Mugabe] memory was really failing and he was getting enfeebled intellectually. I always said to myself that with every day that passed without him resolving the succession conclusively, his chances of managing the succession diminished', Charamba discerned. ${ }^{108}$ Proof of Mugabe's mental regression was lucidly illustrated by his September 2015 opening of a new session of parliament, during which he read the same

\footnotetext{
${ }^{105}$ Terence Ranger, 'Nationalist historiography, patriotic history and the history of the nation: the struggle over the past in Zimbabwe', Journal of Southern African Studies 30, 2 (2004), pp. 215-234.

${ }^{106}$ Interview, Happyton Bonyongwe, Harare, 26 July 2018.

${ }^{107}$ Interview, Enos Nkala, Bulawayo, 28 August 2011; Edgar Tekere, A lifetime of struggle (SAPES Books, Harare, 2009).

${ }^{108}$ Interview, George Charamba, Harare, 24 December 2017.
} 
speech as one he gave in his state of the nation address a month earlier, without detecting the text's similarity. ${ }^{109}$

In addition to Mugabe's fading charismatic authority, his subjection to a subordinate masculinity also contributed to the decline of his authority with generals. Mugabe did not see active combat in the liberation war and never trained as a soldier but he strategically performed militant hegemonic masculinity as ZANU PF's president during the liberation struggle and as Zimbabwe's leader after independence. ${ }^{110}$ Lord Robin Renwick was the head of the UK's Foreign and Commonwealth Office (FCO) Rhodesia Department in the 1970s and one of the important negotiators of the Lancaster House Agreement (1979) that brought about Zimbabwe's independence. Renwick interacted with Mugabe a great deal in the 1970s as part of the UK's diplomatic efforts to end the war in Rhodesia and he best described Mugabe's typical strategic performance of militant hegemonic masculinity:

It was a Robespierre type performance. There he was looking anything but military, as you know he is even mildly effeminate in his manners, but his rhetoric was as hardline as you can imagine. His plan was to seize power through the gun and he said he was making progress in that direction so there is no reason for Britain to get involved, negotiation is a waste of time. So, we got independent African leaders like Nyerere and Machel to force Mugabe to negotiate but Mugabe would always look at me and say 'power springs from the barrel of a gun and I have a postgraduate degree in terrorism'. These were statements by Mugabe several times to me at Lancaster House. ${ }^{11}$

Renwick's account of Mugabe's performances of militant hegemonic masculinity during the independence struggle is corroborated by memoirs of former ZANLA guerrillas. ${ }^{112}$ The scholar Robert Muponde also writes about the ways in which Mugabe, in the post-independence years, imposed masculine 'injunctions' on the state, party and nation, such as that amadoda sibili (real

\footnotetext{
${ }^{109}$ The Guardian, 'Calls for Robert Mugabe to quit after he reads wrong speech at parliament', 15 September 2015 ,

<https:/www.theguardian.com/world/2015/sep/15/robert-mugabe-quit-reads-wrong-speech-zimbabwe-parliament> (20 January 2019).

${ }^{110}$ I borrow the hegemonic masculinity concept from Raewyn Connell. Hegemonic masculinity is the most preferred and respected type of masculinity in a defined milieu. It subordinates the 'feminine' and helps maintain a hierarchy of masculine traditions. See Connell's Masculinities (Polity, Cambridge, 2005).

${ }^{111}$ Interview, Lord Robin Renwick, London, 12 February 2014. Maximilien Robespierre was a French politician who gained notoriety for his leading role in the dictatorial 'reign of terror' in France's 1789-99 revolution.

${ }^{112}$ See for example the ZANLA commander Wilfred Mhanda's, Dzino. memories of a freedom fighter (Weaver Press, Harare, 2011).
} 
men) 'should never show weakness' in politics. ${ }^{113}$ In this masculine canon, Mugabe was the president and commander in chief made of 'steel, war-hardened, unwavering, unblinking and bred on the classical Boy Code'. ${ }^{114}$ In practice Mugabe's standing as indoda sibili (a real man) drew on, for example, his consistent subjugation and seeing off of all his foremost domestic male political challengers, such as Joshua Nkomo, Tekere, Morgan Tsvangirai and Solomon Mujuru, across four decades of rule. Mugabe also withstood Western condemnations, sanctions and isolation for overseeing the post-2000 violent seizure of commercial farms from white Zimbabweans. But then, in February 2015 Mugabe fell to the earth as he was walking down a flight of stairs, from an elevated podium, after addressing thousands of ZANU PF supporters. ${ }^{1.5}$ The imagery of military generals standing in line at the base of the stairs when Mugabe fell down on all fours was a compelling illustration of the indoda sibili and commander in chief's emergent subordinate masculinity. ${ }^{116}$ Moreover, Charamba divulged that 'a frail RG was being beaten at home by Grace and the command [of the military] was aware of it'. ${ }^{117}$ Mugabe's domestic physical abuse, owing to his advanced age and infirmity, at the hands of Grace Mugabe further subjected him to subordinate masculinity, when considered in the milieu of the military, 'the exemplary masculinized institution', as Paul Higate and Marsha Henry regard it. ${ }^{118}$ The ostensible reversal of power relations between Grace Mugabe and Mugabe in the private or domestic sphere found expression in public affairs or matters of state, with some military officers beginning to regard Mugabe as a 'weak' leader and liability. ${ }^{119}$ A perception grew, among military generals, that Grace

\footnotetext{
${ }^{113}$ Robert Muponde, 'Mugabe the man-nation: two views of culture in the construction of masculinities in Zimbabwe' in Sabelo Ndlovu-Gatsheni (ed.), Mugabeism? 'History, politics and power in Zimbabwe (Palgrave Macmillan, New York, 2015), pp. 137-156, p. 139-40.

${ }^{114}$ Ibid., p. 141.

${ }^{11.5}$ Independent, 'Robert Mugabe falls down stairs, tries to get photographers to delete evidence', 5 February 2015, <https://www.independent.co.uk/news/people/robert-mugabe-falls-down-stairs-tries-to-get-photographers-to-deletethe-evidence-10025008.html> (20 January 2019).

${ }^{116}$ Interview, Senior Military Officer 3, Harare, 13 March 2018.

${ }^{117}$ Interview, George Charamba, Harare, 24 December 2017.

${ }^{118}$ Paul Higate and Marsha Henry, 'Engendering (in)security in peace support operations', Security Dialogue 35, 4 (2004), pp. 481-498.

${ }^{119}$ Interview, Senior Military Officer 3, Harare, 13 March 2018.
} 
Mugabe had transmuted into a determiner of presidential decision making. ${ }^{120}$ Civilians such as Kasukuwere and Charamba affirmed that Grace Mugabe was influential in Mugabe's decision to sack Mnangagwa as vice president and in Mugabe's October 2017 cabinet reshuffle, which demoted or dismissed key ministers aligned with Mnangagwa. ${ }^{121}$ During the coup, Mukonori and Charamba both were struck by the degree to which Mugabe had lost his authority of old with generals. "They kept calling RG "old man Machiavelli” and not out of admiration. Reverence was gone. There was much contempt', Charamba opined. ${ }^{122}$ Mukonori went further than Charamba by criticizing Mugabe's subordinates for, over the years, having consciously constructed Mugabe as an irreplaceable iconic leader, only to 'tear him down' through a coup. ${ }^{123}$ Mukonori disclosed:

several years ago Mugabe confided in me that he wanted to retire. Why did he not retire? Political lieutenants. Chiwenga and Mnangagwa pushed him to stay. Azviite tisina imi. Chimbo garai [we cannot do without you. Stay in power]. They must bear some of the responsibility for Mugabe overstaying. They are the same people who later had the guts to do a coup. ${ }^{124}$

The concluding coup motivation centres on Decalo's point that disregarding 'the idiosyncratic factor - the personal element', greatly impoverishes our 'understanding of military upheavals'. ${ }^{125}$ Decalo's reflection is apropos in relation to Zimbabwe's 2017 coup because G40's rising challenge to the Mnangagwa faction threatened to end some politically ambitious generals' personal goals to someday govern Zimbabwe. Chiwenga stood to lose the most personally, amongst political motivated military officers, if Mugabe handed power to G40, hence Chiwenga's decision to lead the coup. As a senior military officer stated in 2014: 'Chiwenga's plan is to succeed ED [Mnangagwa] after ED succeeds Mugabe. When ED is President, Chiwenga will be

\footnotetext{
${ }^{120}$ Ibid.

${ }^{121}$ Interview, Saviour Kasukuwere, Johannesburg, 23 July 2018; Interview, George Charamba, Harare, 24

December 2017.

${ }^{122}$ Interview, George Charamba, Harare, 24 December 2017.

${ }^{123}$ Interview, Father Fidelis Mukonori, Harare, 4 January 2018.

${ }^{124}$ Ibid.

${ }^{125}$ Decalo, Coups and army rule, p. xii.
} 
his Vice-President. There is an alliance between the two'. ${ }^{126}$ Indeed, Chiwenga became Mnangagwa's Vice President after the 2017 coup. Chiwenga was the most politically oriented general in part because he was ZANLA's deputy chief political commissar in the liberation struggle. His political inclination partly derived from his experience as a profoundly political soldier in the 1970 s. $^{1.27}$ Chiwenga's political ambitions were also rooted in a 1965 prophecy given to him by his dying grandfather who, in his youth, was an heir to a chieftainship he eventually did not manage to attain in his lifetime. As described by Chiwenga, his deceasing grandfather prophesied to him: 'what I wanted to achieve [governing] I could not achieve, but you are going to do it. You are Nyikadzino. You are Nyikadzino... you are going to fulfil this destiny'. ${ }^{22}$ Chiwenga made this disclosure in August 2016, soon after he changed his legal name from Constantine Chiwenga to Constantino Guvheya Dominic Nyikadzino Chiwenga. A literal translation of Nyikadzino to English is 'these countries' but if the name is taken in the context of his grandfather's unfulfilled destiny to govern, Nyikadzino denoted Chiwenga's inherited destiny to someday rule the country. Chiwenga combined this sense of destiny to govern with a knack for ruthless political scheming. Chiwenga's 'devious' behind the scenes manoeuvrings in pursuit of his political leadership aspiration led some disapproving military officers to assign him the moniker 'JR Ewing'. ${ }^{129}$ JR Ewing is a fictional character in an illustrious 1970 s to 90 s American television series called Dallas. JR's character on the Dallas show exercises ruthlessness and constant chicanery to further his personal goals. The personal motivations of coup organizers matter greatly when attempting to explain why coups occur, as Decalo rightly pointed out. But coup leaders' personal motivations are not enough, on their own, to create conditions ripe for a coup. Chiwenga could not have hoped to motivate others in the military to stage a coup based

\footnotetext{
${ }^{126}$ Tendi, 'State intelligence'.

${ }^{127}$ Interview, Senior Military Officer 3, Harare, 13 March 2018.

${ }^{128}$ The Sunday Mail, 'Gen Chiwenga and the Nyikadzino prophecy', 26 November 2017,

<http://www.sundaymail.co.zw/gen-chiwenga-and-the-nyikadzino-prophecy/> (20 January 2019).

${ }^{129}$ Interview, Senior Military Officer 1, Harare, 9 December 2017.
} 
on his personal motives alone. Finer's argument that 'the principal motives on which the military tend to act' are almost always 'a mixture... that varies from case to case' is therefore constructive here. ${ }^{130}$ The grievance of independence war veterans in the military about Mugabe's demotion of liberation struggle values and actors, the generalized insecurity of senior military officers and Mugabe's waning authority were an important 'mixture' ripe for a coup, in addition to Chiwenga's personal motivation. Having established the coup motivations, the discussion now enters its final phase - an examination of the coup's eventual catalyst and dynamics.

\section{A coup's fruition}

During the course of a series of 'Youth Interface' rallies in the latter part of 2017, Grace Mugabe frequently attacked Mnangagwa directly while Mugabe mainly resorted to indirect criticisms of his deputy. ${ }^{131}$ On 4 November 2017 Grace Mugabe was booed by a section of ZANU PF supporters at a Youth Interface rally in Bulawayo. Mugabe, enraged, interpreted the booing as organized by Mnangagwa and, in his speech, threatened to dismiss Mnangagwa from government - an act he carried out two days later. ${ }^{132}$ When Mnangagwa was fired, Chiwenga was in China on a scheduled defence business trip. Sibanda, the acting ZDF Commander, contacted Chiwenga to inform him of Mnangagwa's sacking. Chiwenga responded by saying, 'Mnangagwa's life could be at stake so please make sure he is safe' and afterward Sibanda instructed two soldiers to assist Mnangagwa exit Zimbabwe via the Mozambican border. ${ }^{133}$ Days later, ZRP Support Unit officers attempted to arrest Chiwenga at Robert Gabriel Mugabe International Airport, upon his return from China. Chiwenga was shielded from arrest by an army counter operation at the airport,

\footnotetext{
${ }^{130}$ Finer, The man on horseback, p. 52.

${ }^{131}$ News24, 'Grace Mugabe "plotting” VP Mnangagwa "final push”, 21 September 2017,

<https:/www.news24.com/Africa/Zimbabwe/grace-mugabe-plotting-vp-mnangagwa-final-push-report-20170921> (20 January 2019).

${ }^{132}$ News24, 'Mugabe threatens to sack VP as wife booed at rally', 5 November 2017,

<https:/www.news24.com/Africa/Zimbabwe/mugabe-threatens-to-sack-vp-as-wife-booed-at-rally-20171104> (20 January 2019).

${ }^{133}$ Chronicle, 'Gen Sibanda helped ED escape after being fired from govt: VP Chiwenga', 16 July 2018, <http://www.chronicle.co.zw/gen-sibanda-helped-ed-escape-after-being-fired-from-govt-vp-chiwenga/> (20 January 2019).
} 
which was ordered by Sibanda. When the counter operation occurred, the acting Army Commander was Major General Moyo and the stand-in Air Marshal (because Shiri was away in Dubai) was Elson Moyo. ${ }^{134}$ These two commanders and Sibanda were ZIPRA soldiers in the liberation war.

With Mnangagwa sacked and Chiwenga targeted, the acting command's shielding of Chiwenga can be understood as resistance to the continued persecution of former liberation struggle figures. ${ }^{135}$ The bid to arrest Chiwenga also confirmed some insecure top officers' fear that Mugabe was out to purge them. ${ }^{136}$ Sibanda and Chiwenga were not regular cronies. ${ }^{137}$ They belonged to separate rival liberation armies in the independence war and the integration of both armies after 1980 was fractious and acutely violent. A British Military Training and Advisory Team (BMATT) was based in Zimbabwe from 1980 to 2001, to integrate and train the independence army. Sibanda was favoured by BMATT for his abilities as a professional conventional soldier. Tim Toyne-Sewell, a former BMATT commander, regarded Sibanda as 'professional' and 'intelligent'. ${ }^{138}$ Another BMATT commander, Bob Hodges, remarked: 'as BMATT we believed Phillip was one of us'. ${ }^{139}$ Sibanda's proximity to BMATT and higher professional standard resulted in less professional soldiers like Chiwenga derisively identifying him as 'mu British' [the Brit]. ${ }^{140}$ Nonetheless, Sibanda safeguarded Chiwenga from arrest by the police. Sibanda also later conceived the term Operation Restore Legacy. ${ }^{141}$

In the latter part of the week beginning 6 November 2017, generals requested Mugabe to set aside his press briefing session, booked for the morning of Monday 13 November, so that he

\footnotetext{
${ }^{134}$ Interview, Senior Military Officer 3, Harare, 13 March 2018; also see: Zimbabwe Independent, 'How army takeover was executed', 17 November 2017,

<https://www.theindependent.co.zw/2017/11/17/army-takeover-executed/> (20 January 2019).

${ }^{135}$ Interview, Senior Military Officer 4, Harare, 16 December 2017.

${ }^{136}$ Ibid.

${ }^{137}$ Ibid.

${ }^{138}$ Interview, Tim Toyne-Sewell, London, 17 February 2012.

${ }^{139}$ Interview, Bob Hodges, London, 8 October 2012.

${ }^{140}$ Interview, Senior Military Officer 3, Harare, 13 March 2018.

${ }^{141}$ Chronicle, 'Gen Sibanda helped ED'.
} 
could meet them to resolve their disputes with him. ${ }^{142}$ The generals remained open to dialogue but Mugabe refused to engage them and went ahead with his Monday briefing session. Mugabe's snub of discussion with his generals catalyzed the coup because with the option of dialogue off the table, generals' alternatives were limited to aggressive action. Charamba described the turn of events that morning:

we went for the brief and I realized RG was not his usual self. He was irritable, shouting at people like Nhepera [Director General of CIO] and he shouted "shut up" at Mphoko when he was trying to make a point RG thought was nonsensical. RG's refusal to meet the command agitated them even more. That is why they held a press conference that afternoon.... It meant things were now going one way. ${ }^{1.3}$

Chiwenga's afternoon address to the press was attended by dozens of senior officers from the army and air force with liberation war experience. Chiwenga's speech mostly resembled a liberation history lecture. He presented the side-lining of liberation war participants in ZANU $\mathrm{PF}$ as 'counter-revolutionary' and described a series of 'counter-revolutionary' episodes in the liberation histories of both ZANLA and ZIPRA, pointing out that these historical counterrevolutions were all 'defused by the military'. ${ }^{14}$ Chiwenga expanded:

It is pertinent to restate that the Zimbabwe Defence Forces remain the major stockholder in respect to the gains of the liberation struggle and when these are threatened we are obliged to take corrective measures.... The current purging and cleansing process in ZANU PF which so far is targeting mostly members associated with our liberation history is a serious cause for concern for us in the Defence Forces. We must remind those behind the current treacherous shenanigans that when it comes to matters of protecting our revolution, the military will not hesitate to step in. The current purging which is clearly targeting members of the party with a liberation background must stop forthwith. ${ }^{155}$

Chiwenga did something else on 13 November: he called a security meeting with generals and other liberation war veterans commanding key army and air force formations. An officer recounted Chiwenga's utterances at the meeting:

JR said 'we now have an urgent security situation. The liberation legacy is under threat. The country is collapsing. If we do not act as an army things will get out of control. So I am going to require the cooperation of everybody. We will do this together. We will temporarily take over the country. If anyone tries to fire or

\footnotetext{
${ }^{142}$ Interview, George Charamba, Harare, 24 December 2017.

${ }^{143}$ Ibid.

${ }^{14}$ Newsday, 'Chiwenga calls Mugabe to order, 14 November 2017,

<https://www.newsday.co.zw/2017/11/chiwenga-calls-mugabe-order/> (20 January 2019).

${ }^{145}$ Ibid.
} 
arrest one of us, that is an attack on us all. No one will be fired. No one will be victimized. Are we together?' Soldiers started shouting yes, yes, yes! Soldiers gave their support to JR thinking this was for the good of country. ${ }^{146}$

A related account of the nature and outcome of the security meeting is offered by the writer Ray

Ndlovu:

Chiwenga privately brought together the most senior army generals. 'Are you happy with what is going on?'... Chiwenga is said to have told the generals. 'We are done with Mugabe. They cannot do this to Mnangagwa' is the response that Chiwenga was given almost in unison, in what is said to have been a highly charged meeting. 'This man [Mnangagwa] is our commander'.

Both abovementioned accounts bore resemblance to Nordlinger's conception of coups as a vote of no confidence or political contest occurring in the military. Political beliefs shaped the outcome of Zimbabwe's 2017 coup, in contradiction of Singh's coordination theory, which ignores the consequence of political views. Mugabe lost majority support amongst decisive liberation war veterans in the military because his leadership was now perceived as a 'threat' to the 'liberation legacy'. In Chiwenga's estimation, the military had to act and there would be no retribution for their action, which was for 'the good of the country'. Chiwenga cast the military as the upholder of national interest in a manner that fits one of Finer's portrayals of custodianship. Finer notes that some militaries 'see it as their duty to arbitrate.... when some convulsion or decision of the civil authorities seems to them to threaten what they think are the permanent interests of the nation' ${ }^{148}$

According to Singh, the goal of coup leaders' pre-coup meetings with other officers and, especially, their ID on radio and television is to present the coup as 'a fait accompli, that they have broad support within the armed forces, and that any resistance to the coup is on its last legs. This is the part of the [ID] broadcast that matters, not the boilerplate justifications offered for the coup'. ${ }^{149}$ Singh also maintains the primary audience of the ID is soldiers in the military.

\footnotetext{
${ }^{146}$ Interview, Senior Military Officer 1, Harare, 9 December 2017.

${ }^{147}$ Ndlovu, In the jaws of the crocodile, p. 105.

${ }^{148}$ Finer, The man on horseback, p. 31.

${ }^{149}$ Singh, Seizing Power, p. 30.
} 
However, Chiwenga's addresses mentioned above and Major General Moyo's ID, discussed earlier in the article, placed greater emphasis on the coup's virtues. They did not forcefully reinforce the coup's victory. Major General Moyo's ID was approximately 6 minutes long. Only 5 minutes and 30 seconds into his ID did Major General Moyo seek to directly address soldiers by saying: 'to members of the defence forces, all leave is cancelled and you are all to return to your barracks with immediate effect. To the other security services, we urge you to cooperate for the good of our country'. ${ }^{150}$ These were hardly forceful words of victory or a statement that all resistance was destroyed. More significantly, immediately after Major General Moyo broadcast the ID, Chiwenga's 13 November press conference speech and liberation war songs were then played ad nauseam on state-controlled radio and television. ${ }^{1.51}$ As stated before, Chiwenga's press conference address dealt with liberation history, values and the military's time-honoured role to defuse counter-revolutionary threats to the liberation legacy. If Singh is correct that the primary audience of coup broadcasts is military members, then the goal of broadcasts resonant with appeals to liberation history and struggle values and the military's destined responsibility to defend them, was the suasion of liberation war veterans controlling all key command posts in the military to support the coup. That there was no counter coup operation from within the military command vindicated the resonance of Chiwenga's appeals to liberation history and ethos.

The 2017 coup was not the first-time generals adopted an arbitration role, shaped by liberation struggle history and values. In 2002, when Mugabe and ZANU PF rule were under electoral threat from an opposition party with no connection to the independence war, the then ZDF Commander Zvinavashe made a public declaration that the military would 'only stand in support of those political leaders that will pursue Zimbabwean values, traditions and beliefs for which thousands of lives were lost in the pursuit of Zimbabwe's hard-won independence, sovereignty,

\footnotetext{
${ }^{150}$ Author's personal recording of Major General Sibusiso Moyo's ZBC live broadcast, 15 November 2017.

${ }^{1.51}$ Discussion with ZBC Official, Harare, 27 July 2018.
} 
territorial integrity and national interests. ${ }^{152}$ Zvinavashe's statement was publicly reiterated by some serving senior military officers with liberation war experience before elections in 2005 and 2008, and these officers became increasingly involved in electoral politics in support of ZANU PF. When Mugabe lost the March round of the 2008 presidential election, the officers waged a campaign of nationwide political violence against opposition voters, in order to bolster Mugabe's chances of victory in the runoff poll three months later. ${ }^{153}$ Thus, the influence of political beliefs on the 2017 coup's outcome should be seen against the backdrop of past political interferences by many liberation war veterans in the military.

Some generals alleged that there was an attempt from outside the military to counteract the coup. The accusation ran thus: Bonyongwe contacted Shiri in Dubai, beseeching him to return to Zimbabwe instantly so they could collaborate with Chihuri's ZRP Support Unit in counteracting the coup. ${ }^{154}$ Shiri was said to have then forwarded Bonyongwe's communication to Chiwenga, via mobile phone. ${ }^{1.55}$ It was also alleged that Chihuri had a ZRP Support Unit stationed in a small town called Gokwe but it was intercepted by soldiers, presumably on its way to Harare. ${ }^{156}$ Bonyongwe challenged the accuracy of this account of events:

I never met with Chihuri to plan how to reverse the coup and I never asked Shiri to come back so we could lead that operation. Chihuri and Shiri can confirm that if you interview them. When the coup happened, I was now the Minister of Justice. It simply does not make sense that a Minister of Justice can lead a counter operation. I am a war veteran [of the liberation war]. I was also uncomfortable with the direction the former president was going. He was supposed to leave power to those he travelled with in the liberation war. I was with my other comrades on that point. The liberation is important. ${ }^{1.57}$

Bonyongwe's standpoint was more plausible than the claim he sought to lead a counter coup operation. Recall the scholar Hills' beforementioned point about the tactical training and

\footnotetext{
${ }^{152}$ Author's copy of 'Statement by Zimbabwe Defence Forces (ZDF) Commander Vitalis Musungwa Zvinavashe', Harare, 9 January 2002. For a complete explanation of the context in which Zvinavashe made his statement, see Tendi, 'Ideology, civilian authority'.

${ }^{153}$ See, Eldred Masunungure (ed.), Defying the winds of change: Zimbabwe's 2008 elections (Weaver Press, Harare, 2009).

${ }^{154}$ Interview, Father Fidelis Mukonori, Harare, 4 January 2018; Interview, Senior Military Officer 3, Harare, 13 March 2018.

${ }^{155}$ Interview, Senior Military Officer 3, Harare, 13 March 2018.

${ }^{156}$ Ibid.

${ }^{157}$ Interview, Happyton Bonyongwe, Harare, 26 July 2018.
} 
institutional capacity challenges police generally encounter. The allegation a Justice Minister planned to lead an incapacitated police force into action against a well-equipped army and air force is therefore implausible. Significantly, for the article's critique of Singh's disregard of political beliefs in his conceptualization of coup dynamics as coordination, Bonyongwe asserted the influence of a historically formed normative construction about who ought to govern Zimbabwe, in his decision not to oppose the coup, when he stated that Mugabe 'was supposed to leave power to those he travelled with in the liberation war'. Liberation struggle values motivated other war veterans outside the military to support the coup. For example, the enormous citizens' rally and march in solidarity with the military in Harare on 18 November were organized by independence war veterans outside the military. ${ }^{158}$ The massive march turnout heightened pressure on Mugabe to resign. ${ }^{159}$ Singh mistakenly downplays the potential impact of civilian mass action for or against a coup in his contention that only intra-military dynamics matter for the success of coups.

In spite of this, Singh's study does enhance our comprehension of certain aspects of coups. For instance, one of Singh's findings is that coups staged by generals are successful $68 \%$ of the time, compared to $48 \%$ for coups organized by middle ranking officers and $32 \%$ for coups managed by junior soldiers. ${ }^{160}$ Operation Restore Legacy therefore had, at its inception, a relatively high likelihood of success because it was organized by generals, not soldiers in the lower ranks. Coups by generals have a higher success rate, since generals 'have an easier time avoiding detection because they can meet in groups to discuss matters of national policy as part of their professional duties. This provides cover for behaviour that might be considered suspicious in lower-ranking officers' ${ }^{161}$ This 'cover' enabled Zimbabwean generals to meet and discuss the feasibility of a

\footnotetext{
${ }^{158}$ Interview, Colonel Tshinga Dube, Harare, 20 December 2017.

${ }^{159}$ Interview, Senior Military Officer 3, Harare, 13 March 2018; Interview, Father Fidelis Mukonori, Harare, 4 January 2018.

${ }^{160}$ Singh's Seizing power.

${ }^{161}$ Ibid., p, 79.
} 
coup and what operational tactics they might employ. Generals are also usually numerically fewer than their junior officers and many of them will have served with each other for many years in various combat and non-combat roles, as they rose up military ranks. Accordingly, members of a military's upper ranks are often quite familiar with each other, meaning that if there is consensus around the need to stage a coup, their coup plans can 'build on existing bonds of trust and they can avoid the risks inherent in bringing a stranger into a plot'. ${ }^{162}$ In the Zimbabwean case, some bonds of trust went back as far as the 1970s independence war, a point which supports the article's contention that liberation struggle solidarity values were essential to the 2017 coup's success. One particular bond of trust that aided the coup's success was the durable link between Chiwenga and Major General Anselem Sanyatwe, commander of the Presidential Guard. A military officer reflected: 'Sanyatwe and Chiwenga have worked very closely for years. Presidential Guard is the president's line of defence but when the coup happened, Sanyatwe was not with Mugabe. Sanyatwe was with Chiwenga so Mugabe had no protection'. ${ }^{163}$ Finally, generals have access to organizational intelligence, which Singh tells us, enables them to establish, in advance of the coup, potential impediments and the 'preferences, tactical readiness and beliefs of other key officers' ${ }^{164}$ Chiwenga, for instance, tightly controlled MI and from about 2009 its spying steadily expanded into the sphere of civilian intelligence gathering, giving him access to far reaching information on affairs in and outside the military. ${ }^{165}$

\footnotetext{
${ }^{162}$ Ibid., 79-80.

${ }^{163}$ Interview, Senior Military Officer 2, Harare, 10 January 2018.

${ }^{164}$ Singh, Seizing power, p, 80.

${ }^{165}$ Tendi, 'State intelligence'.
} 


\section{Conclusion}

The article argues Operation Restore Legacy was a coup by military generals, which had important commonalities with coups elsewhere in Africa. It maintains that exceptionalist notions of the coup as 'special' or 'very Zimbabwean' by some scholars are misplaced and they to some extent reinforce Zimbabwean generals' self-serving attempts to represent Operation Restore Legacy as different from standard coups. Turning to the coup's motivations, Decalo points up the weight of coup leaders' personal ambitions and idiosyncrasies in his discussion of coup motives. The article acquiesces with Decalo by highlighting the influential role of personal motives in Zimbabwe's 2017 coup but it finds a mixed bag of at times overlapping motivations as a more compelling way of capturing the coup's complex motives. The article's identification of an assorted bag of coup motives supports Finer's conclusion that coup motivations are inevitably mixed and the mix generally varies between coups. Additionally, the article contends the coup's catalyst was Mugabe's rejection of his generals' suggestion that he postpone his 13 November morning briefing session, to allow for critical closed-door discussions with top officers in order to iron out their increasing differences. Mugabe's rebuff of dialogue limited generals' options to force by way of a coup. Prevailing analyses inaccurately pinpoint Mnangagwa's sacking from government as having catalyzed the coup.

In terms of the coup's dynamics, the article argues the coup was a vote of no confidence in Mugabe's leadership by liberation war veterans in the military, because they regarded him as progressively discarding liberation struggle ethos and participants in the ruling ZANU PF party. Liberation war veterans had command of all key army and air force formations when they turned against Mugabe, resulting in the absence of a counter coup operation within the military. The article's argument about the coup's dynamics problematizes game theoretic approaches of 
understanding coup dynamics, which negate the role of political beliefs in shaping coup outcomes. The article's discussion of coup dynamics concentrated on Singh's coordination theory, the most advanced game theoretic approach to comprehending coup dynamics. The qualitative dimension of Singh's study of coup dynamics in Africa rests solely on accounts of participants in several triumphant and botched historical coups in Ghana. However, when Ghana attained independence from British colonialism in 1957 it did not do so via an armed liberation struggle, making its independence time military markedly different from those in African countries such as Angola, Mozambique, Namibia and Zimbabwe, where ideological liberation armies contributed to struggles for independence and later became significant, if not dominant, parts of post-independence militaries. Singh's work narrows or homogenizes the rich and diverse experiences and ideational guides of militaries in Africa. In Zimbabwe, soldiers from two former liberation armies have controlled the post-independence military across four decades and, for many of them, liberation struggle values remain an important guide for political action. Liberation war veterans in the military could not brook politicians without ideational and active participant connections to the independence struggle securing control of the state, hence their support for the coup. 'Coups d'état are annoying not only for practicing politicians but also from the point of view of the political scientist' because they are capricious - 'almost by definition they are mortal enemies of orderly hypotheses and concepts' ${ }^{166}$

\footnotetext{
${ }^{166}$ Walter Laqueur quoted in Luttwak, Coup d'état, p. xxxv.
} 